\title{
IKAN PATIN: PELUANG EKSPOR, PENANGANAN PASCAPANEN, DAN DIVERSIFIKASI PRODUK OLAHANNYA
}

\author{
Th. Dwi Suryaningrum*)
}

\begin{abstract}
ABSTRAK
Ikan patin merupakan komoditas hasil budidaya perikanan yang pasarnya cukup menjanjikan. Dalam kurun waktu dua tahun terakhir ini, permintaan ikan patin meningkat dua kali lipat. Potensi pasar tersebut perlu dimanfaatkan dengan lebih menggalakkan budidaya ikan patin di Indonesia yang potensi lahannya cukup luas. Pasar ikan patin selama ini masih dikuasai Vietnam dengan ekspor dalam bentuk fillet dan produk olahan berbasis surimi. Selain dipasarkan dalam bentuk fillet, ikan patin sangat cocok untuk diolah menjadi berbagai macam produk berbasis surimi yang trend pasarnya semakin meningkat. Ikan patin dapat diolah secara tradisional maupun modern sehingga dapat meningkatkan nilai tambah ikan patin secara berarti. Akan tetapi dalam era globalisasi ini, pemasaran produk ikan hasil budidaya ke berbagai negara menghadapi banyak hambatan. Tantangan yang harus dihadapi di pasar internasional adalah produk perikanan diharuskan memenuhi persyaratan yang cukup ketat dalam hal kualitas, keamanan pangan, dan ketertelusurannya (traceability). Dalam industri pengolahan ikan patin akan dihasilkan limbah yang cukup banyak yaitu sekitar $67 \%$ dari total ikan patin. Limbah tersebut dapat diolah dan dimanfaatkan menjadi gelatin, konsentrat protein, tepung ikan, silase, atau minyak biodiesel sehingga dapat memberikan nilai tambah dalam industri ikan patin. Agar industri ikan patin dapat berkembang di Indonesia maka diperlukan dukungan dari pemerintah, lembaga riset, dan swasta untuk mengembangkan sentra budidaya ikan patin di suatu lokasi.
\end{abstract}

KATA KUNCI: ikan patin, pemasaran, pengolahan ikan, dan pemanfaatan limbah

\section{PENDAHULUAN}

Ikan patin atau yang dalam dunia perdagangan dikenal dengan catfish merupakan komoditas baru dalam dunia perikanan. Ikan ini baru dipasarkan sebagai komoditas hasil budidaya perikanan selama satu dasawarsa terakhir ini. Sebelumnya masyarakat penggemar seafood jarang mengenalnya dibandingkan dengan udang, ikan tuna, dan salmon. Namun sekarang ikan patin menjadi komoditas yang sangat penting dan popular karena pasarnya berkembang dengan pesat. Salah satu negara yang berhasil mengembangkan budidaya ikan patin dan merajai pasar adalah Vietnam. Produksi budidaya ikan patin di Vietnam naik sangat pesat. Tercatat pada tahun 1977 produksinya baru mencapai 22.000 ton dan pada tahun 2006 meningkat menjadi 800.000 ton. Hal ini dapat memberikan lapangan pekerjaan kepada ribuan penduduk Vietnam dalam bidang budidaya, pengolahan, dan pemasaran ikan patin (Anon., 2007). Semula pemasaran patin Vietnam menggunakan label catfish, tetapi setelah kasus tuduhan dumping di AS, nama yang digunakan adalah nama lokal Vietnam yaitu basa dan tra. Sedangkan untuk pasaran Uni Eropa dan pasar lainnya ikan patin Vietnam menggunakan label Pangasius. Ikan patin atau basa identik dengan Vietnam sebagai negara pengekspor terbesar di dunia. Dengan tingginya laju pertumbuhan ekspor catfish, pada tahun 2007 diharapkan volume ekspor catfish Vietnam mencapai 1 juta ton dengan nilai 1 milyar USD. Ikan patin dipasarkan dalam bentuk fillet beku atau disebut "dory". Kini produk tersebut tersebar di supermarket dan hypermarket di Singapura, Malaysia, Thailand, serta beberapa negara lain. Ikan patin juga telah mengubah kebiasaan makan konsumen Amerika dan Eropa yang menunya biasanya ikan salmon menjadi ikan patin, karena harganya yang murah, kualitasnya yang baik, serta tersedia setiap saat (Anon., 2007a). Produk tersebut diyakini dapat meningkatkan vitalitas karena kualitasnya yang baik serta bebas dari bahan kimia.

Indonesia juga mempunyai potensi untuk menjadi produsen dan eksportir ikan patin, namun budidaya ikan patin baru berkembang di Jambi, Sumatera Selatan, Jawa Barat, dan Kalimantan Barat. Salah satu jenis ikan patin Indonesia yang sangat prospektif untuk dibudidayakan adalah ikan patin jambal yang dagingnya berwarna putih. Ikan patin jenis ini sudah dibudidayakan di Jambi dengan target produksi pada tahun 2007 sebesar 29 ton (Purnomo, 2007). Mengingat peluang pasar ikan patin yang masih luas, maka budidaya ikan patin di Indonesia perlu lebih digalakkan lagi, dengan memperhatikan berbagai isu di pasar global. Menurut Micholowski (2007), tantangan yang harus dihadapi pasar internasional

\footnotetext{
*) Peneliti pada Balai Besar Riset Pengolahan Produk dan Bioteknologi Kelautan dan Perikanan
} 
adalah produk perikanan diharuskan memenuhi persyaratan yang cukup ketat, dalam hal kualitas, keamanan pangan dan ketertelusurannya (traceability). Salah satu pasar yang paling ketat persyaratannya adalah Uni Eropa, yang menekankan bahwa keamanan pangan harus terjamin sejak produksi sampai ke meja makan dan dapat ditelusuri riwayatnya (Noer, 2007). Oleh karena itu, di Vietnam Asosiasi Eksportir dan Produsen Seafood (VASEP) telah mengembangkan budidaya ikan patin berdasarkan Good Aquaculture Practices (GAP), sehingga ikan patin Vietnam tidak mengalami kesulitan untuk menembus pasar ekspor Uni Eropa, Amerika, dan negara lainnya. Ikan patin menjadi sangat populer karena budidayanya mudah, pertumbuhannya cepat, dan mudah beradaptasi dengan berbagai lingkungan. Di samping itu, teknologi budidaya ikan patin sudah berkembang dan dapat dilakukan dengan berbagai sistem yaitu dengan karamba di sungai-sungai, waduk, kolam atau situ.

Berkembangnya budidaya ikan patin di Vietnam, diikuti dengan pesatnya perkembangan industri pengolahan ikan seperti industri surimi dan produk berbasis surimi di negara tersebut. Surimi merupakan produk setengah jadi, berupa daging lumat yang dibersihkan dan mengalami pencucian berulang-ulang sehingga sebagian besar, bau, darah, lemak, dan pigmen hilang. Dari surimi tersebut kemudian dapat diolah menjadi berbagai macam produk yang bentuk dan warnanya menarik sehingga konsumen tertarik membelinya. Tersedianya sarana tempat penjualan ikan yang modern di berbagai supermarket menyebabkan ketersediaan produk perikanan yang semakin beragam. Selama ini aneka produk yang berbasis surimi seperti fish cake, jelly fish, udang tiruan, crab tiruan, bakso, nugget, dan lain-lain yang tersedia pada space frozen food supermarket masih diimpor dari Thailand, Malaysia, dan Vietnam. Daging ikan patin sangat potensial untuk dijadikan surimi karena cukup tebal, berwarna putih serta teksturnya elastis dan kenyal. Sifat ini dimungkinkan karena ikan patin dapat diolah dari bahan baku ikan yang masih hidup. Diversifikasi pengolahan ikan patin menjadi produk siap olah dan siap saji akan meningkatkan nilai tambah yang cukup berarti karena pasarnya cukup terbuka, sehingga permintaan produk ini meningkat secara berarti setiap tahunnya.

\section{PRODUKSI DAN PEMASARAN IKAN PATIN}

Ikan patin merupakan salah satu spesies ikan budidaya air tawar yang saat ini menjadi primadona komoditas ekspor. Perkembangan budidaya ikan patin di Indonesia semakin pesat, terutama di daerah Jawa Barat, Sumatera Selatan, Jambi, Riau,
Bengkulu, Lampung, dan Kalimantan. Perkembangan budidaya yang cukup pesat tersebut terutama dipicu oleh peluang pasar yang masih terbuka terutama untuk ekspor. Permintaan daging ikan patin yang berwarna putih sangat besar dan terus meningkat. Salah satu jenis spesies ikan patin asli Indonesia yang telah berhasil dibudidayakan dan berdaging putih adalah patin jambal (Pangasius djambal Bleeker). Namun karena fekunditas dan daya tetas telurnya rendah, maka produksi massal benih ikan patin jambal ini sulit dilakukan. Oleh karena itu, Loka Riset Pemuliaan dan Teknologi Budidaya Perikanan Air Tawar (LRPTBPAT) Sukamandi telah membuat hibrid ikan patin jenis Pasopati. Ikan patin ini merupakan hasil silangan antara ikan patin siam (Pangasius hypothalamus) yang mempunyai daging berwarna kekuning-kuningan, diintroduksi dari Thailand dan telah berkembang di Indonesia, dengan ikan patin jambal yang mempunyai daging yang berwarna putih. Ikan patin pasopati mempunyai keragaan yang baik dengan daging berwarna putih, pertumbuhan yang cepat, daya toleransi kualitas air yang baik, resistensi patologis, serta memungkinkan untuk diproduksi secara besarbesaran sehingga potensial sebagai komoditas andalan baru perikanan budidaya (Tahapari et al., 2007). Menurut data statistik perikanan budidaya tahun 2001, produksi ikan patin (dari budidaya kolam, keramba dan jaring apung, serta sawah) adalah sebesar 11.118 ton. Produksi ikan patin naik menjadi 32.375 ton pada tahun 2005, tetapi pada tahun 2006 turun menjadi 31.490 ton (Anon., 2007c). Pada tahun 2007 diharapkan produksi dapat meningkat dengan mulai digalakkannya produksi budidaya ikan patin di beberapa daerah.

Pasar ikan patin sangat menjanjikan. Vietnam yang merupakan negara penghasil ikan patin terbesar telah mengekspor fillet ikan patin ke-65 negara tujuan. Pada tahun 2006 volume ekspor ikan patin naik dua kali lipat bila dibandingkan dengan tahun 2005. Data ekspor ikan patin Vietnam pada tahun 2005-2006 dapat dilihat pada Gambar 1. Uni Eropa merupakan pasar utama untuk ekspor ikan patin dengan volume ekspor mencapai 46,9\%. Spanyol, Belanda, dan Polandia merupakan negara pengimpor fillet ikan patin dengan volume yang cukup besar. Rusia juga merupakan pasar yang sangat prospektif bagi ikan patin Vietnam. Impor ikan patin meningkat secara berarti pada tahun 2006. Amerika Serikat dan Cina masing-masing mengimpor $11 \%$ dan $9 \%$ dari total ekspor ikan patin Vietnam. Peningkatan yang cukup signifikan juga terjadi pada pasar India dan Timur Tengah. Di Singapura, Malaysia, dan Thailand fillet ikan patin kini diolah lebih lanjut menjadi makanan siap olah dan diekspor ke berbagai negara. Sedangkan di Inggris, fillet ikan patin diolah menjadi 


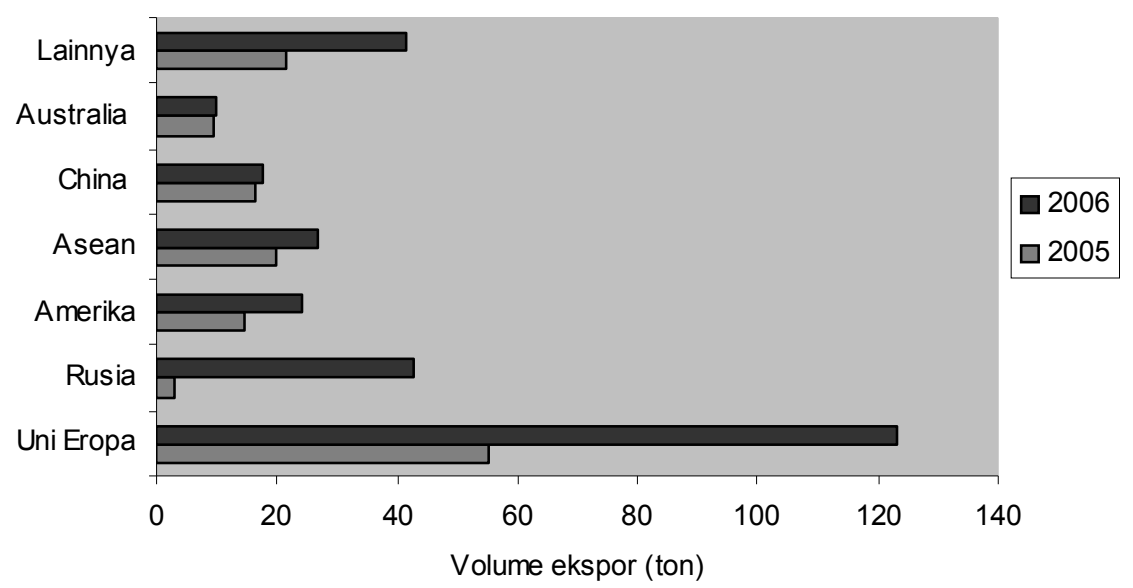

Gambar 1. Ekspor ikan patin Vietnam ke beberapa negara.

makanan siap saji dan dipasarkan di jaringan retail (Anon., 2007a).

Berbagai tantangan yang dihadapi dalam pemasaran ikan patin hasil budidaya antara lain adalah adanya hambatan tarif dan non tarif sebagai dampak dari sistem perdagangan global khususnya setelah terbentuk perdagangan dunia WTO (World Trade Organization) serta masalah subsidi (Putro, 2007). Tarif bea masuk untuk impor produk perikanan yang cukup tinggi dan tidak merata di negara maju akan melemahkan daya saing produk perikanan Indonesia di pasaran internasional. Sebagai contoh Uni Eropa memberikan penurunan tarif udang beku dari normal $14 \%$ menjadi $5 \%$ bagi negara-negara bekas jajahannya yang tergabung dalam ACP (Afrika, Carribea, dan negara-negara Pasifik) termasuk Papua New Guinea dan Suriname. Demikian juga Amerika Serikat yang membebaskan bea masuk dari negara-negara Pakta Andean, sehingga Indonesia menghadapi persaingan yang sangat ketat. Sedangkan hambatan non tarif menyangkut mutu dan keamanan pangan. Oleh karena itu, untuk mengantisipasi adanya hambatan tersebut, standar Good Aquaculture Practices (GAP) harus diterapkan dalam industri perikanan budidaya. Demikian juga penerapan GMP (Good Manufacturing Practices atau cara produksi pangan olahan yang baik), SSOP (Sanitation Standard Operating Procedures), dan HACCP (Hazard Analysis Critical Control Point) dalam industri pengolahan perikanan harus diterapkan dan dimonitor secara terus menerus oleh pemerintah, sehingga produk yang diolah dapat diterima di pasar global.

\section{PENANGANAN PASCAPANEN IKAN PATIN}

Ikan patin biasanya dijual dalam keadaan hidup, sehingga pemanenan harus dilakukan secara hati-hati agar tidak banyak ikan yang menggelepar, dan mengurangi resiko kemungkinan terjadinya luka. Pemanenan ikan dapat dilakukan dengan cara mengeringkan kolam kemudian menjaring dan menangkapnya. Ikan patin yang dipelihara di Keramba Jaring Apung (KJA) dipanen dengan cara mengangkat KJA dari air kemudian mengeluarkan ikan dari jaring. Bila ikan akan dijual dalam keadaan hidup maka ikan tersebut harus segera dikemas dengan menggunakan wadah atau tangki. Transportasi ikan patin biasanya dilakukan dengan menggunakan sistem pengangkutan terbuka. Sistem ini dilakukan karena waktu pengangkutan ikan patin tidak lama, yaitu dari kolam ke pengumpul atau dari pengumpul ke pasar. Faktor yang harus diperhatikan selama pengangkutan adalah kandungan oksigen terlarut. Oksigen terlarut sangat dipengaruhi oleh suhu, kepadatan ikan, dan tingkat aktivitas ikan (Shoemaker, 1991). Suhu media/air yang digunakan untuk mengangkut ikan harus cukup rendah, yaitu berkisar antara $18-20^{\circ} \mathrm{C}$. Hal ini untuk memperlambat respirasi dan metabolisme ikan, serta aktivitas ikan selama transportasi. Pengangkutan ikan yang terlalu padat akan mempercepat penurunan oksigen terlarut, peningkatan suhu, serta metabolit ikan lainnya. Namun pada dasarnya ikan patin merupakan ikan yang daya tahannya cukup tinggi, sehingga mudah untuk diangkut hidup.

\section{DIVERSIFIKASI PENGOLAHAN IKAN PATIN}

Ikan patin dapat dimanfaatkan secara menyeluruh mulai dari kepala, daging, sirip, tulang, telur, isi perut, dan kulit. Sebagian besar ikan patin dipasarkan dalam bentuk fillet beku dan produk olahan lainnya. Oleh karena sifatnya yang mudah busuk, maka ikan patin dibekukan sehingga dapat didistribusikan ke berbagai pasar. 


\section{a) Pembekuan Ikan Patin}

Dalam perdagangan terdapat bermacam-macam produk ikan patin beku, yaitu ikan patin tanpa kepala dan ekor (head and tail less), fillet yang belum dikuliti (skin on), fillet yang sudah dikuliti (skin less), dan breaded fillet ikan patin. Pembekuan adalah proses pendinginan pada suhu yang sangat dingin hingga hampir semua air yang ada dalam fillet ikan patin membeku. Umumnya pembekuan dilakukan pada suhu $-18^{\circ} \mathrm{C}$ atau lebih rendah sehingga dapat membunuh $10-95 \%$ total mikroba (Haryadi, 2007). Produk ikan patin beku dapat disimpan cukup lama, yaitu berbulan-bulan bahkan bisa lebih dari 1 tahun. Selama pembekuan, pertumbuhan mikroorganisme dalam fillet ikan patin akan terhambat. Faktor-faktor dasar yang mempengaruhi mutu produk akhir fillet beku adalah mutu bahan baku, penanganan sebelum pembekuan, metode dan kecepatan pembekuan, suhu penyimpanan dan fluktuasi suhu, waktu penyimpanan, kelembaban lingkungan penyimpanan, serta sifat bahan kemasan yang digunakan.

Pembekuan dapat dilakukan dengan cara memaparkan produk dengan udara dingin (air blast freezing), meletakkan ikan pada pelat beku (contact plate freezer) dengan cara mencelupkan produk atau menyemprotkan cairan refrigeran $\mathrm{CO}_{2}$ dan nitrogen cair dingin ke produk (cryogenic freezing), atau dengan cara membekukan produk dengan larutan garam yang didinginkan (Brine immersion)(Fawzya et al., 2007). Proses pembekuan harus dilakukan dengan cepat, yaitu penurunan suhu dari $0^{\circ} \mathrm{C}$ menjadi $-5^{\circ} \mathrm{C}$ dalam waktu tidak lebih dari 2 jam, kemudian diteruskan dengan pembekuan dalam cold storage sehingga suhu mencapai $-30^{\circ} \mathrm{C}$ pada akhir pembekuan.

Ikan patin biasanya diolah dari ikan yang masih hidup, sehingga kesegaran dan mutu hasil olahan sangat baik apabila proses pembekuannya dilakukan secara cepat. Akan tetapi perlu diperhatikan bahwa dalam industri pengolahan ikan patin untuk tujuan ekspor, terutama ekspor ke Uni Eropa, penerapan GMP, SSOP, serta HACCP harus dilakukan untuk memberikan jaminan mutu dan keamanan pangan. Ikan patin yang akan di fillet dimatikan terlebih dahulu dengan cara memasukkannya ke dalam es sehingga pada saat ikan mati, darah akan terkonsentrasi di sepanjang tulang belakang ikan patin. Mematikan ikan patin dengan cara memukul bagian kepala akan menyebabkan fillet ikan patin berlumur darah dan berpengaruh pada warna produk yang dihasilkan. Ikan patin kemudian diproses lebih lanjut sesuai dengan disposisi produk yang diinginkan. Untuk produk ikan patin potong kepala, segera setelah dimatikan, ikan tersebut dipotong bagian kepala dan ekornya, lalu isi perutnya dikeluarkan dan kemudian dicuci untuk menghilangkan darah serta kotoran lainnya. Ikan kemudian dikemas dan siap untuk dibekukan.

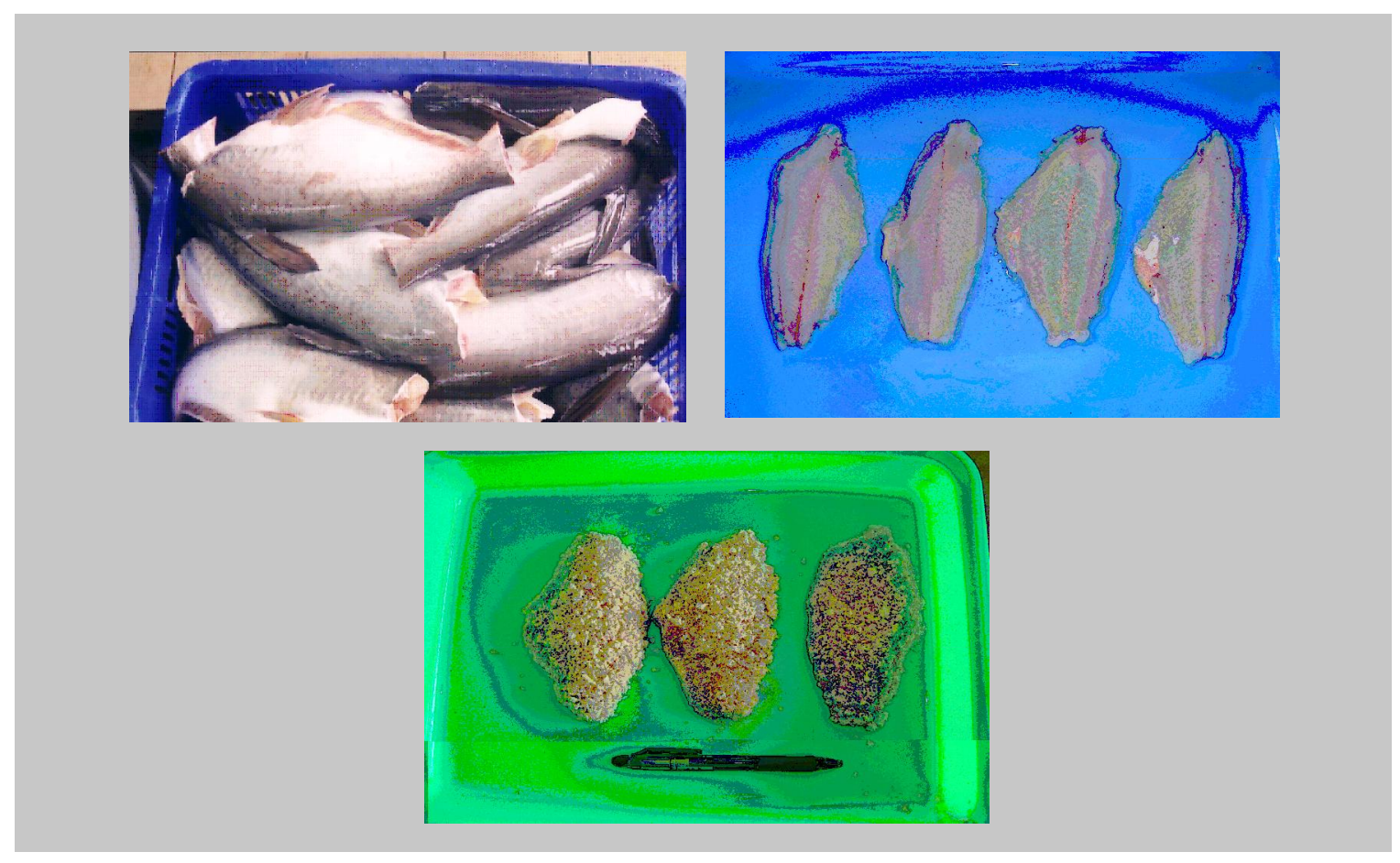

Gambar 2. Ikan patin potong kepala, fillet dan breaded ikan patin. 
Untuk fillet ikan patin, setelah ikan tersebut dipotong kepalanya, daging ikan di-fillet dengan menggunakan pisau khusus sehingga daging terpisah dari tulangnya. Fillet yang diperoleh selanjutnya dapat dihilangkan kulitnya, kemudian dicuci sampai bersih. Fillet ikan kemudian dikemas dengan berat $0,5 \mathrm{~kg} /$ kemasan dan $1 \mathrm{~kg} / \mathrm{kemasan}$. Adakalanya untuk memperbaiki penampilan fillet ikan patin agar lebih mengkilat dan putih, pengolah merendamnya dalam larutan Sodium Tripolifosfat (STPP). Fungsi dari polifosfat adalah meningkatkan kemampuan protein ikan untuk mengikat air sehingga dapat mengurangi kehilangan air ketika produk dicairkan. Walaupun diizinkan, batas maksimum penggunaan STPP adalah $0,5 \%$. Perendaman dalam larutan polifosfat dengan konsentrasi yang lebih tinggi dari 0,5\% dapat menambah berat sehingga berat produk yang tercantum dalam label tidak menunjukkan berat yang sebenarnya (Anon., 2007b).

Fillet ikan patin juga diperdagangkan dalam bentuk breaded. Produk ini lebih disukai oleh konsumen karena dapat segera disajikan (siap saji). Untuk mendapatkan cita rasa breaded ikan patin, maka sebelum di breaded ikan direndam dalam larutan bumbu. Bumbu yang digunakan untuk breaded ikan patin sama dengan bumbu yang digunakan untuk mengolah fish finger yaitu bawang bombay, bawang putih, lada, gula, garam, dan MSG. Fillet ikan direndam dalam larutan bumbu selama 30 menit. Butter mix terbuat dari campuran tepung gandum, maizena, serta bumbu-bumbu seperti merica, bumbu perisa, baking soda, serta kuning telur. Butter mix dilarutkan dalam air es sehingga terbentuk adonan yang kental. Daging fillet ikan patin yang akan di breaded dengan bread crumb dimasukkan dalam butter mix kemudian dilumuri bread crumb dengan cara menggulungkan ke dalam bread crumb. Breaded ikan patin kemudian dikemas dan dibekukan untuk dipasarkan.

\section{b) Pengolahan Ikan Patin menjadi Produk Siap Saji}

Meningkatnya jumlah wanita pekerja dalam era globalisasi ini menjadikan produk siap saji menjadi pilihan konsumen untuk santapan keluarga. Menurut data pasar ikan internasional, ikan yang diolah dalam bentuk siap saji seperti breaded, bakso, nugget mempunyai nilai tambah yang cukup tinggi dibandingkan ikan dalam bentuk mentah. Sementara permintaan produk siap saji meningkat $22 \%$ selama 3 tahun terakhir, demikian juga nilai tambah yang diperoleh.

Ikan patin merupakan salah satu jenis ikan yang sangat cocok untuk diolah menjadi surimi. Dagingnya yang tebal dan berwarna putih, serta dimungkinkan diolah dari bahan baku ikan yang masih hidup, akan menghasilkan surimi yang bermutu tinggi. Uji folding test (uji daya lipat) terhadap surimi yang diolah dari daging ikan patin menghasilkan grade AA dengan kekuatan gel dapat mencapai lebih dari $1000 \mathrm{~g} / \mathrm{cm}^{2}$ meskipun daging surimi sudah disimpan selama 2 bulan dalam cold storage (Suryaningrum et al., 2007). Proses pengolahan surimi dari daging ikan patin memerlukan air yang banyak karena kandungan lemak ikan patin cukup tinggi. Surimi ikan patin sebaiknya diolah dari ikan patin yang sudah di-fillet dan dihilangkan kulitnya (skin less). Surimi yang diolah dari ikan patin yang masih ada kulitnya (skin on) dapat menyebabkan daging lumat ikan patin mengandung serpihan-serpihan kulit yang terikut ketika proses pelumatan daging dengan menggunakan mesin meat bone separator. Adanya serpihan kulit ikan patin yang berwarna hitam pada surimi merupakan benda asing yang tidak dikehendaki dalam perdagangan.

Untuk membantu mengeluarkan lemak dari daging ikan patin maka selama pencucian ditambahkan natrium bikarbonat sebanyak $0,5 \%$ dari volume air yang digunakan untuk pencucian. Setelah proses pencucian selesai, kandungan air daging lumat kemudian dikurangi dengan menggunakan meat dehydrator atau dengan menggunakan mesin pengepres. Daging lumat yang sudah dicuci dan dikurangi kandungan airnya kemudian dicampur dengan bahan cryoprotectant berupa sukrosa dan sorbitol, agar tidak terjadi kerusakan struktur protein selama pembekuan. Sedangkan untuk meningkatkan daya ikat air dan menghasilkan tekstur produk yang lebih lembut biasanya ke dalam surimi ditambahkan polifosfat dalam bentuk sodium tripolifosfat (Peranginangin et al., 1999). Surimi kemudian diaduk dengan menggunakan mesin pengaduk (mixing and kneading), dicetak dalam pan/blok untuk kemudian disimpan pada suhu beku. Surimi ikan patin siap diolah menjadi berbagai macam produk .

Surimi ikan patin dapat diolah menjadi berbagai produk berbasis surimi karena teksturnya cukup kenyal dan baunya netral. Tersedianya mesin pengolah ikan dengan aneka cetakan membuat surimi dapat diolah menjadi berbagai macam bentuk dan warna yang menarik. Berbagai produk berbasis surimi, seperti kamaboko, chikuwa, udang imitasi, crab, fish jelly, fish cake, dan lain-lain, kini mengisi gerai ruang pendingin di berbagai supermarket dan hypermaket di kota-kota besar di Indonesia. Pada prinsipnya pengolahan surimi menjadi berbagai macam produk adalah mencampur surimi dengan garam, tepung, air, lada, minyak sayur, dan flavour dengan menggunakan mesin pengaduk. Adonan kemudian dibentuk sesuai dengan produk yang diinginkan. Produk kemudian 
dapat direbus, dikukus, digoreng, atau dibakar. Untuk memperoleh gel yang elastis dan kenyal ada 2 prinsip yang harus dipahami, yaitu proses pengadukan pada saat membuat adonan dan pembentukan gel pada saat pemasakan. Pada proses pengadukan, suhu selama pengadukan harus dijaga tetap rendah yaitu sekitar $10^{\circ} \mathrm{C}$ atau kurang dengan menambahkan es. Sedangkan pada proses pemanasan dilakukan 2 tahap, tahap pertama dipanaskan pada suhu $40-60^{\circ} \mathrm{C}$, kemudian dilanjutkan pada pada suhu $70-90^{\circ} \mathrm{C}$ (Kammuri \& Fujita, 1985).

\section{PEMANFAATAN LIMBAH IKAN PATIN}

Industri fillet ikan patin menghasilkan rendemen sekitar 33\% sedangkan sisanya sebanyak $67 \%$ merupakan limbah yang berupa kulit, kepala, tulang, isi perut, serta belly. Apabila limbah ini tidak segera ditangani, maka tidak tertutup kemungkinan akan menyebabkan terjadinya pembusukan sehingga dapat menimbulkan bau serta pencemaran lingkungan yang cukup serius. Limbah ini nilainya sangat rendah namun jika dimanfaatkan secara optimal akan memberikan nilai tambah yang cukup berarti. Limbah ikan patin dapat diolah sebagai bahan pangan, tepung ikan, bahan untuk farmasi, atau pupuk.

\section{a) Pengolahan Limbah Ikan Patin menjadi Produk Makanan}

Industri fillet ikan patin menghasilkan limbah berupa serpihan daging fillet yang jika diolah lebih lanjut dapat meningkatkan nilai tambah $40-45 \%$ (Sorenson, 2007). Serpihan daging tersebut dapat diolah menjadi berbagai macam produk berbasis daging lumat seperti nugget, fish cake, otak-otak, dan siomay. Sedangkan kepala dan isi perut dapat difermentasi lebih lanjut menjadi kecap ikan, yang banyak digunakan sebagai bumbu untuk berbagai macam masakan Cina. Ikan patin banyak mengandung lemak terutama dibagian bawah perut yang disebut belly. Seperti halnya ikan laut, lemak pada ikan patin merupakan lemak jenuh namun tidak mengandung asam lemak omega-3. Lemak ini dapat diolah sebagai cooking oil. Telur ikan patin merupakan limbah yang paling berharga dibandingkan limbah lainnya. Telur ini dapat dijual di pasar atau supermaket dalam bentuk segar, asap, atau fermentasi, yang dikemas menarik.

Limbah kulit ikan patin dapat diolah lebih lanjut menjadi produk makanan seperti kerupuk kulit. Namun salah satu kendala yang dihadapi adalah warna kulitnya yang hitam sehingga produk menjadi kurang menarik. Walaupun demikian rasanya yang gurih menyebabkan kerupuk kulit ini banyak digemari oleh masyarakat sebagai makanan camilan atau lauk. Sedangkan masyarakat di Sumatera Selatan (Palembang) memanfaatkannya sebagai empekempek yang merupakan makanan khas Palembang. Pengolahan kulit ikan patin menjadi kerupuk sangat sederhana, kulit ikan dibersihkan dari sisa daging yang melekat, kemudian dicelupkan dalam air panas sekitar 2 menit untuk menghilangkan sisik dan kotoran yang melekat. Kulit ikan patin kemudian direndam dalam larutan bumbu yang terdiri atas garam $2 \%$, bawang merah, dan bawang putih selama 3 jam kemudian dijemur sampai kering. Kerupuk kulit ikan patin dapat diperdagangkan dalam bentuk mentah atau digoreng sehingga siap untuk disantap.

Limbah ikan patin juga dapat dimanfaatkan sebagai bahan baku untuk hidrolisis protein dengan menggunakan enzim protease Sebelum diproses limbah ikan dipanaskan terlebih dahulu, untuk menginaktifkan enzim. Dengan proses ini diperoleh protein yang dapat dikonsumsi oleh manusia. Hasil penelitian menunjukkan bahwa hidrolisis protein dengan enzim akan menghasilkan produk dengan kandungan asam amino yang sangat tinggi.

\section{b) Limbah Ikan Patin untuk Industri}

Limbah ikan patin berupa tulang dan kulit ikan dapat diolah lebih lanjut menjadi gelatin dan kolagen. Gelatin banyak dimanfaatkan dalam industri pangan dan farmasi, sedangkan kolagen banyak dimanfaatkan untuk industri kosmetik. Gelatin dari ikan yang hidup di daerah tropis mempunyai titik leleh yang lebih tinggi dibandingkan dengan ikan yang hidup di daerah dingin. Gelatin biasanya diolah dari tulang dan kulit babi, yang haram bagi umat muslim, sementara gelatin dari tulang dan kulit sapi seringkali dikawatirkan mengandung penyakit sapi gila. Oleh karena itu, permintaan gelatin ikan di pasar global semakin meningkat, terutama di negara-negara yang sebagian besar penduduknya muslim.

Di Vietnam, limbah kulit ikan patin dibekukan dan dijadikan komoditas ekspor untuk bahan baku industri gelatin di berbagai negara. Penelitian ekstraksi gelatin dari kulit ikan patin yang telah dilakukan oleh Peranginangin et al. (2004) menunjukkan bahwa gelatin yang diolah dari kulit ikan patin yang direndam dalam larutan asam pada $\mathrm{pH} 3$ selama 12 jam dan suhu ekstraksi $90^{\circ} \mathrm{C}$ menghasilkan rendemen, viskositas, kekuatan gel yang terbaik. Gelatin yang diolah dengan cara tersebut memenuhi persyaratan gelatin mutu pangan kelas $\mathrm{A}$. Tulang ikan patin juga dapat dimanfaatkan menjadi food suplement yaitu sebagai sumber kalsium. Hasil penelitian menunjukkan bahwa kalsium tulang ikan yang 
dicampurkan ke dalam makanan ikan menunjukkan pertumbuhan ikan yang lebih baik.

Dalam pengolahan surimi ikan patin dihasilkan limbah lemak yang berbentuk padatan sebesar $25 \%$ dari total daging lumat ikan patin yang dicuci (Suryaningrum et al., 2007). Jumlah limbah yang cukup besar akan menjadi masalah lingkungan apabila tidak dimanfaatkan dengan baik. Lemak ikan patin tersebut merupakan alternatif sebagai biodiesel seperti halnya minyak kelapa sawit. Lemak ikan patin juga dapat dimanfaatkan sebagai bahan baku untuk pembuatan sabun mandi, sabun cair, atau sampo. Proses pembuatan sabun sangat sederhana, tidak memerlukan peralatan yang canggih serta bahanbahannya mudah diperoleh di toko-toko kimia. Lemak yang merupakan limbah ikan patin dipanaskan, kemudian disabunkan dengan menambahkan Natrium hidroksida $(\mathrm{NaOH}) 32 \%$ dan diaduk dengan menggunakan mixer, sehingga diperoleh larutan yang kental. Sabun yang kental kemudian ditambah dengan dekstrin $1 \%$ dan surfaktan $1,8 \%$ dan diaduk hingga merata. Selanjutnya ditambahkan parfum dan pewarna kemudian dicetak dalam cetakan sabun selama 1 hari sehingga diperoleh sabun yang padat. Sedangkan untuk sabun cair, penyabunan dilakukan dengan menggunakan Kalium hidroksida $(\mathrm{KOH}) 36 \%$, sedangkan dekstrin diganti dengan $\mathrm{CMC} 2 \%$. Larutan kental yang diperoleh kemudian didiamkan semalam lalu diencerkan dan dipanaskan kembali. Larutan kemudian disaring dan diberi parfum sehingga diperoleh sabun cair. Sedangkan untuk sampo, proses penyabunan yang dilakukan sama dengan sabun mandi yaitu menggunakan $\mathrm{NaOH} 32 \%$. Larutan kental yang terbentuk kemudian dicairkan dan ditambah dengan surfaktan Emal TD 40\%. Larutan kemudian diberi warna dan parfum serta bahan pengawet asam benzoat. Larutan kemudian dipanaskan kembali dan ditambah larutan $\mathrm{NaCl} 1 \%$ sehingga diperoleh sampo yang jernih. Sampo yang diperoleh kemudian dimasukkan dalam wadah tertutup dan siap untuk dipasarkan (Wijana et al., 2005)

\section{c) Pengolahan Limbah Ikan Patin menjadi Tepung Ikan}

Tepung ikan biasanya diolah dari ikan laut yang masih segar, sehingga dihasilkan tepung ikan yang kandungan proteinnya tinggi serta mengandung asam lemak omega-3. Sedangkan tepung ikan yang diolah dari limbah ikan patin yang berupa kepala, isi perut, serta tulang ikan mengandung protein dan omega-3 yang rendah. Oleh karena itu, tepung ikan yang diolah dari ikan patin digolongkan dalam mutu rendah sebagai pakan ikan. Tepung ikan ini hanya dapat dimanfaatkan untuk pakan ayam atau babi, namun formulasi dengan bahan lain yang mengandung protein yang tinggi dapat digunakan sebagai pakan ikan selain ikan patin. Dalam budidaya ikan, tepung ikan tidak boleh diberikan pada spesies yang sama, misalnya tepung ikan yang diolah dari ikan patin tidak boleh dijadikan sebagai pakan ikan patin.

\section{d) Pengolahan Limbah Ikan Patin menjadi Silase}

Selain dimanfaatkan sebagai tepung ikan, limbah ikan patin dapat diolah sebagai silase, yaitu dengan cara menurunkan $\mathrm{pH}$ di bawah 4,5. Silase dapat diolah secara asam dan biologi. Pengolahan silase secara asam sangat sederhana, tidak memerlukan peralatan yang komplek dan modal yang besar. Limbah ikan patin berupa tulang, kepala, dan isi perut ditambah dengan asam seperti $\mathrm{HCl}$, asam propionat, asam formiat sebesar 3-5\%. Untuk mempercepat proses ensilasi limbah sebaiknya dihancurkan, sehingga proses penurunan $\mathrm{pH}$ 3-4 segera tercapai. Proses selanjutnya adalah autolisis yang disebabkan aktivitas enzim. Untuk menghindari proses pembusukan karena bakteri dan penurunan kandungan protein, pada proses ini dapat

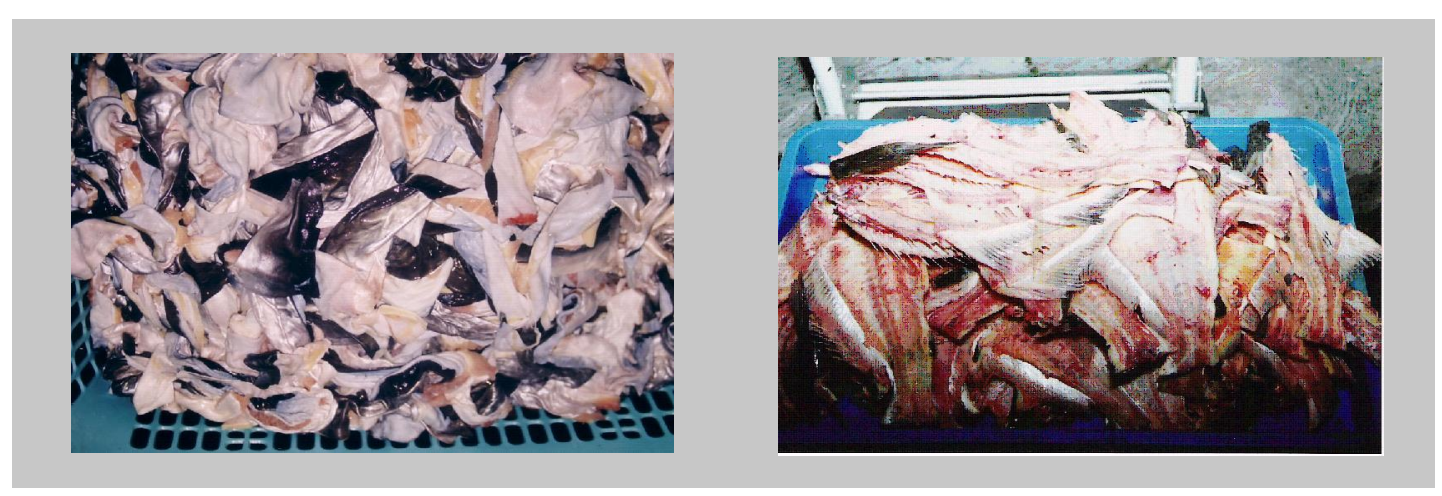

Gambar 3. Limbah kulit dan tulang ikan patin sebagai bahan mentah untuk produk pangan dan industri. 
ditambahkan antibakteri dan antioksidan. Selama proses ensilasi, silase akan terpisah menjadi 3 fase, yaitu minyak, protein, dan padatan. Protein yang diperoleh dalam proses ini kemudian di panaskan pada suhu $80-85^{\circ} \mathrm{C}$ untuk meningkatkan kandungan protein serta produk menjadi lebih stabil (Sorenson, 2007). Protein yang terkandung dalam silase ini sebesar $17-30 \%$ dan dapat digunakan sebagai pakan ternak.

\section{PENUTUP}

Tersedianya lahan produktif untuk pengembangan budidaya ikan patin di beberapa daerah, semestinya mendorong Indonesia untuk mampu tampil sebagai produsen ikan patin seperti halnya Vietnam. Oleh karena itu, peran strategis pemerintah (pusat maupun daerah), lembaga riset, swasta, serta perbankan diharapkan dapat meningkatkan tumbuhnya industri budidaya ikan patin yang selama ini belum dioptimalkan. Selain itu pengembangan budidaya ikan patin dengan sistem sentra yang merupakan pusat kegiatan budidaya di satu kawasan/lokasi tertentu yang menggunakan bibit, teknologi, sarana yang sama, serta menghasilkan produk yang sejenis perlu digalakkan. Dengan sistem sentra ini, maka usaha budidaya akan menjadi lebih efisien dan dapat mencapai skala ekonomis untuk berdirinya industri pengolahan ikan patin, penanganan limbah dapat terkendali, dan mudah untuk melakukan pembinaan atau inovasi. Tumbuhnya sentra budidaya ikan patin ini akan meningkatkan perekonomian nasional melalui penerimaan devisa dan membuka lapangan kerja baik disektor budidaya (hatchery dan pembesaran), pengolahan dan pemasaran sebagai sumber pendapatan bagi ribuan nelayan serta pembudidaya ikan. Pengembangan budidaya ikan patin dan inovasi produk olahan ikan patin diharapkan mampu mengisi kebutuhan pasar di Uni Eropa, Rusia, Timur Tengah, Australia, dan Amerika yang saat ini didominasi oleh ikan patin "basa" dari Vietnam.

\section{DAFTAR PUSTAKA}

Anonim. 2007a. Ikan patin Vietnam terus melaju. Warta Perikanan. Edisi Mei 2007. No 45.

Anonim. 2007b. Marjin air untung atau buntung ? Warta Perikanan. Edisi Juni 2007. No 46 : 14-17.
Anonim. 2007c. Statistik Kelautan dan Perikanan Tahun 2006. Pusat Data Statistik dan Informasi. Departemen Kelautan dan Perikanan. Badan Pusat Statistik Republik Indonesia.

Anonymous. 2007. Catfish 2007. Conference-attracts global audience. Infofish International 4 : 26-32.

Fawzya, Y.N., Murniyati., dan Suryaningrum, T.D. 2007. Persyaratan pengolahan produk perikanan. Kumpulan Hasil Penelitian Pascapanen Perikanan. Balai Besar Riset Pengolahan Produk dan Bioteknologi Kelautan dan Perikanan. Badan Riset Kelautan dan Perikanan. p. 3-16.

Haryadi, R.D. 2007. Teknologi pembekuan pangan. Food Review. Edisi Juli 2007.

Kammuri, Y. and Fujita, T. 1985. Surimi based product and fabrication processes. Proceedings of The International Symposium on Engineered Seafood Including Surimi. p. 254-263.

Micholowski, C. 2007. Industri perikanan dan kelautan menghadapi tahun 2007. Food Review. Edisi Januari 2007.

Noer, H.F. 2007. Tantangan global dalam industri pangan. Food Review. Edisi Januari 2007.

Peranginangin, R., Wibowo, S., dan Fawya, Y.N. 1999. Teknologi Pengolahan Surimi. Instalasi Penelitian Perikanan Laut Slipi. Balai Penelitian Perikanan Laut Puslitbangkan. Departemen Pertanian. 24 pp.

Peranginangin, R., Haq, N., Ma'ruf, F.W., dan Rusli, A. 2004. Ekstraksi gelatin dari kulit ikan ikan patin (Pangasius hypothalamus) secara proses asam. J. Penel. Perik. Indonesia. 10 (3) : 76-84.

Purnomo, A. 2007. Menembus pasar ekspor produk perikanan Indonesia. Food Review. II (7) : p. 12-15.

Putro, S. 2007. Implikasi pasar global terhadap perikanan budidaya. Bulletin eM-eS. PT Matahari Sakti. Edisi ke 14 : p. 16-21.

Schoemaker, R. 1991. Transportation of live and processed seafood. Infofish Technical Handbook. 3. $29 \mathrm{pp}$.

Sorenson, N.K. 2007. Trun pangasius by products into cash. Infofish International. 4 : 34-38.

Suryaningrum, T.D., Ikasari, D., Peranginangin, R., Muljanah, I., Murniyati., dan Syamdidi. 2007. Laporan Teknis Riset Peningkatan Nilai Tambah Udang dan Ikan Air Tawar. Balai Besar Riset Pengolahan Produk dan Bioteknolgi Kelautan dan Perikanan Jakarta. 96 pp.

Tahapari, E., Sularto, dan Hadi, W. 2007. Hasil Riset Budidaya Ikan Patin. Makalah disampaikan pada acara lokakarya hasil riset. 14 pp.

Wijana, S., Hidayat, N., dan Hidayat, A. 2005. Mengolah minyak goreng bekas. Tekno Pangan. Trubus Agrisarana. 47 pp. 